\title{
Last glacial-Holocene temperatures and hydrology of the Sea of Galilee and Hula Valley from clumped isotopes in
}

\section{Melanopsis shells}

\author{
Shikma Zaarur ${ }^{1}$, Hagit P. Affek ${ }^{1,2}$, and Mordechai Stein $^{3}$ \\ ${ }^{1}$ Department of Geology and Geophysics, Yale University (shikmaz@gmail.com \\ , hagit.affek@yale.edu) \\ ${ }^{2}$ Now at The Institute of Earth Sciences, The Hebrew University of Jerusalem \\ (hagit.affek@mail.huji.ac.il). \\ ${ }^{3}$ Geological Survey of Israel (motistein@gsi.gov.il )
}

Submitted: February 2015; Revised version submitted: September 2015, second revision submitted: November 2015

25 pages, 2 tables, 4 figures.

Supplementary Information includes 1 document and 5 tables 


\section{Abstract}

The carbonate clumped isotope $\left(\Delta_{47}\right)$ thermometer was applied to fresh water snails

3 (Melanopsis spp.) grown in the waters of the Sea of Galilee and Hula Valley, in the north of

4 Israel. Modern shells, grown at known temperatures agree with the $\Delta_{47}-T$ calibration of Zaarur et

5 al. (2013). Fossil Melanopsis shells from 2 locations, Gesher Bnot Ya'aqov (at the southern tip

6 of the Hula Valley) and the Sea of Galilee provide a temperature record for the region during the

7 time interval of the past 20 kyrs. Glacial temperatures are $\sim 5^{\circ} \mathrm{C}$ cooler than mid-Holocene and

$8 \sim 3{ }^{\circ} \mathrm{C}$ cooler than modern, similar to other records in the region. These $\Delta_{47}$-derived temperatures

9 are combined with $\delta^{18} \mathrm{O}$ of the shell carbonate to calculate the oxygen isotopic composition of

10 the habitat waters. Contrary to global trends and other regional records, reconstructed $\delta^{18} \mathrm{O}_{\text {water }}$

11 values increase from the late glacial through the Holocene. This reversed signal reflects a

12 decrease in the relative contribution of snow-melt to the watershed post-LGM and a transition to

13 a more rain dominated inflow. A fairly constant difference in $\delta^{18} \mathrm{O}_{\text {water values between the Hula }}$

14 Valley and Sea of Galilee waters, suggests that the hydrological relationship of the two water

15 bodies had remained constant, with the temperature changes playing only a minor role in the 16 extent of evaporation of the Sea of Galilee relative to the Hula.

17 


\section{Introduction}

Oxygen isotope compositions in lake carbonates provide important constraints on the paleolimnological, hydrological, and environmental conditions in terrestrial environments (Gat,

21 1995; Kolodny et al., 2005; Leng, 2006; Li and Ku, 1997). The oxygen isotope composition of a

22 mineral, when precipitated at isotopic equilibrium, depends on both the temperature of mineral

23 formation and the isotopic composition of the water in which it grows. Due to the complexity of

24 hydrological variations controlling the oxygen isotopic composition of the relevant waters, $\delta^{18} \mathrm{O}$

25 has an inherent limitation in its application to paleoclimate in the terrestrial environments. To 26 deduce water $\delta^{18} \mathrm{O}$ values, independent estimates of temperature are required. In some cases

27 these may be obtained from other paleothermometers such as $\mathrm{Mg} / \mathrm{Ca}$ or $\mathrm{Sr} / \mathrm{Ca}$ in calcium 28 carbonates or by the alkenone unsaturation method. These proxies, however, were designed 29 primarily for marine settings and their use in lacustrine environments is not straightforward. 30 Alternatively, inferring water temperature requires an independent estimate of the isotopic 31 composition of the water. In the oceans, estimates of variations in continental ice volume provide 32 a constraint on ocean water $\delta^{18} \mathrm{O}$ values, and hence on surface or deep water temperatures at the 33 glacial-interglacial time scale. On land, however, ice volume has only an indirect and partial 34 control on freshwater $\delta^{18} \mathrm{O}$. Carbonate clumped isotopes paleothermometry allows to derive the 35 temperature of mineral formation and is independent of the isotopic composition of the water.

36 These independent constrains on water temperatures allow to calculate $\delta^{18} \mathrm{O}$ values of the 37 respective waters.

The Quaternary climate of the Eastern Mediterranean, or Levant, has been the subject of many studies (as reviewed by Rambeau, 2010; Roberts et al., 2008; Robinson et al., 2006). 40 Terrestrial climate in this region is directly influenced by the Mediterranean Sea and is thought 
41 to have been so in the past (Bar-Matthews et al., 2003; Begin et al., 2004; Enzel et al., 2008;

42 Roberts et al., 2008). This sea-land relationship therefore provides a concrete framework for the

43 understanding of the terrestrial response to climate change.

44 This region is of particular interest in the context of Early Human behavior, response and 45 adaptation to environmental change, as the Levant has been inhabited by Early Humans and is 46 thought to have been the main route for the migration of Early Humans out of Africa (Bar-Yosef 47 and Belfer-Cohen, 2013; Frumkin et al., 2011). It is generally thought that water availability 48 plays a key role in human habitation, past and present, making the study of hydrological 49 response to climate change relevant to both archeological studies in the region and to future 50 climate change.

51 Today, precipitation in the Eastern Mediterranean occurs predominantly during the 52 winter months. The Mediterranean Sea is the main vapor source with most rainstorms resulting 53 from air derived from North East Atlantic fronts, that pass over Europe and then accumulate 54 moisture from the warm waters of the Mediterranean Sea (Rindsberger et al., 1983). 55 Occasionally precipitation is associated with sub-tropical air passing directly over the 56 Mediterranean Sea (Dayan, 1986). A minor source of moisture that mostly affects Southern 57 Israel, is the Red Sea Trough which is part of a Southern Indian Ocean low-pressure thermal 58 system (Tsvieli and Zangvil, 2005). These modern climatic systems provide the framework for 59 thinking of variations in the Late Quaternary climate system with the understanding that specific 60 storm trajectories and rainfall patterns might have been different during glacial times.

62 isotopes and alkenone unsaturation records in the Mediterranean Sea (Almogi-Labin et al., 2009; 63 Martrat et al., 2004), speleothems (Affek et al., 2008; Bar-Matthews et al., 2003), lake sediments 
64 (e.g., Kolodny et al., 2005), and pollen (Cheddadi and Rossignolstrick, 1995; Langgut et al., 65 2011; Rossignol-Strick and Paterne, 1999). Here we use carbonate clumped isotopes of fresh water gastropod shells (Melanopsis spp.) collected from Gesher Bnot Ya'aqov, at the southern tip of the Hula Valley and from the Sea of Galilee (Figure 1) to reconstruct the last glacialHolocene temperatures and hydrological conditions in this region.

\section{Methodology}

\subsection{Geological and hydrological settings}

The modern Sea of Galilee is a fresh water monomictic lake in the Northern Jordan River Valley, Israel (Figure 1). The lake is a remnant of larger water-bodies that occupied the Kinnarot Basin during the Late Pleistocene-Early Holocene (Stein, 2014). Surface water temperatures range between $15^{\circ} \mathrm{C}$ in winter and $29^{\circ} \mathrm{C}$ in summer, with a mean annual temperature of $\sim 24^{\circ} \mathrm{C}$ (Serruya, 1978). The Sea of Galilee evolved as a flow-through lake with its most important inlet being the Jordan River that drains the Hula Valley, and flows into the Sea of Galilee from the north. Today, the Jordan River contributes about half of the total water input to the Sea of Galilee with the rest being direct rainfall and underwater springs (Gvirtzman, 2002). The Jordan River is predominantly fed by three karst springs: Dan ( $50 \%)$, Banias ( 25\%) and Hatzbani $(\sim 25 \%)$ that are recharged by rainfall and snow melt from the Trans-Lebanon mountains (Gvirtzman, 2002). The Sea of Galilee is shallow (40 m at the deepest location) with a large surface area and is therefore subject to a high degree of water loss by evaporation (35\% of input to the lake; Gvirtzman, 2002). The only natural outflow from the Sea of Galilee is through the Southern Jordan River outlet that flows towards the terminal Dead Sea. This southern outlet has been dammed since 1932, such that the modern-day lake is essentially terminal. 

hypersaline lakes filling the Dead Sea basin (e.g., Stein, 2001; Stein, 2014). The surface water elevation and the size of these lakes were determined by inflow/evaporation and local topography with topographic sills at the Yarmouk River delta and Wadi Malih (40 km south of the modern Sea of Galilee) at $~ 200$ and $\sim-260$ m below sea level (bsl), respectively (Bartov et

92 al., 2002; Hazan et al., 2005) separating the lakes when water levels dropped below these 93 elevations. High water stands during the last glacial period led to the expansion of the Sea of 94 Galilee and Lake Lisan (the precursor of the Dead Sea) so that they overflew the sills (Hazan et 95 al., 2005). Sea of Galilee water level reconstruction, performed by radiocarbon dating of paleolake shorelines, indicates fluctuations between $\sim 220$ and $175 \mathrm{~m}$ bsl during the past 40 kyrs 97 (Hazan et al., 2005; Stein, 2014). The highest lake levels occurred between 26 and 24 ka BP when Lake Lisan and the Sea of Galilee converged. Two events of water level drop, at $\sim 23.8 \mathrm{ka}$ $\mathrm{BP}$ (the onset of Heinrich event $\mathrm{H} 2$ ), and at $\sim 17 \mathrm{ka} \mathrm{BP}$, resulted in lakes separation and a retreat 100 to the approximate size and elevation of the modern lakes (Hazan et al., 2005). Abrupt events of 101 102 (Stein, 2014).

Particularly relevant for this study is the dating of lake levels from the Ohalo-II 104 archeological site to $22 \mathrm{ka} \mathrm{BP}$ (Nadel et al., 2001), as we analyzed materials from the nearby 105 Tel Beit Yerach and Shaldag Beach sites. The high quality of the preservation of both the 106 structures and fragile materials at the Ohalo-II archeological site had been suggested to result 107 from a quick and gentle burial shortly after human occupation at the site, leading to its 108 abandonment (Nadel et al., 2001). The quick and gentle submergence hints to its proximity to the 109 lake waters, and suggests a shallow water, evaporative environment. The depositional 
110 environment during the H2 lake retreat was studied by Lev et al. (2014), who described the area

111 as "lake margin". We refer to samples of similar age from the nearby Shaldag Beach and Tel

112 Beit Yerach as belonging to the "Sea of Galilee", bearing in mind that they are not necessarily

113 representative of the bulk lake waters, but rather the lake shore.

114 Lake Hula occupies the northern part of the Jordan River Valley, north of the Sea of

115 Galilee at $\sim 70 \mathrm{~m}$ asl (Figure 1). The shape of the lake is thought to have been approximately 116 constant since its formation at the early Pleistocene (Horowitz, 1978). Prior to the artificial

117 drainage of Lake Hula in 1957 the Jordan River flowed through the Hula Valley and created a 118 shallow, marsh-like, lake environment. The paleo-hydrological setting of the Hula Valley has not 119 been well studied such that it is not clear whether our sampling site (see below) belonged in the 120 past to a shallow lake or to a slow flowing river; in either case, the geographical location implies 121 that these water served as input to the Sea of Galillee. Here we refer to these samples according 122 their modern-day location, as collected from Gesher Bnot Ya'aqov, at the southern tip of the 123 Hula Valley.

124

$125 \quad 2.2$ Melanopsis snails

126 Melanopsis snails are fresh water gastropods that are widespread in the entire Near East,

127 including isolated springs in the deserts (Tchernov, 1975). They inhabit rivers, lakes and 128 marshes, and are particularly abundant in habitats that are rich in succulent aquatic vegetation 129 (Moshkovitz and Magaritz, 1987). They are rock dwellers and can be found at depths of up to $130 \sim 10 \mathrm{~m}$. In anaerobic muddy environments such as the Sea of Galilee they are restricted to the 131 water surface at the shore (Tchernov, 1975). Melanopsis snails live for several years and feed on 132 algae. Their aragonitic shell (roughly $0.5 \times 1.5 \mathrm{~cm}$ in size) is coated by an organic layer that 
133 erodes shortly after the snail dies (Lev et al., 2007). Two species were investigated in this study 134 Melanopsis costata (Olivier, 1804) and Melanopsis buccinoidea (Olivier, 1801). One sample, 135 from Gesher Yossef, was identified as a hybrid of Melanopsis buccinoidea x costata (also 136 described as M. saulcy; Bourguignat, 1853).

\subsection{Sample collection}

Modern Melanopsis snails were collected live together with their habitat water from the

140 Sea of Galilee, and from springs and streams along the Jordan River Valley (Figure 1). Water 141 temperatures measured at time of collection, spanned between $16-26{ }^{\circ} \mathrm{C}$ (Table 1). Note that 142 these water temperatures are summer temperatures and do not necessarily reflect the mean 143 temperature that the snails were exposed to during growth. Fossil shells were collected in 2 main 144 locations: The Jordan River banks (north of Gesher Bnot Ya'aqov, at the southern tip of the Hula 145 Valley), and the shores of the Sea of Galilee (a trench dug at Shaldag Beach at the Southern 146 shore of the Sea of Galilee, near the old lake outlet of the southern Jordan River, and from the 147 nearby shore deposits at the northern side of Tel Beit Yerach). The samples from the Sea of 148 Galilee were collected by Hazan et al. (2005). Additionally, a number of modern and fossil 149 bivalve shells (Corbicula sp. and an unknown species) were collected from the Jordan River and 150 Gesher Hapkak (Tables 1 and 2).

\subsection{Analytical methods}

154 and potential biases due to growing season preferences. Shell material was sub-sampled for $\delta^{18} \mathrm{O}$ 155 analysis by continuous-drilling (using a New Wave Research Micromill) along the growth axis 
156 of the shell from the aperture towards the apex. Sampling distance was defined by the powder

157 fraction size of $\sim 200 \mu \mathrm{g}$, required for the $\delta^{18} \mathrm{O}$ measurements. The carbonate was digested using

$158103 \% \mathrm{H}_{3} \mathrm{PO}_{4}$ at $25{ }^{\circ} \mathrm{C}$ using standard procedures for GasBench carbonate analysis. Water $\delta^{18} \mathrm{O}$

159 was also analyzed using a GasBench system, through equilibration with $0.3 \% \mathrm{CO}_{2}$ in $\mathrm{Helium}$.

160 Water and shell $\delta^{18} \mathrm{O}$ and shell $\delta^{13} \mathrm{C}$ were measured using a Thermo DeltaPlus XP mass

161 spectrometer. Typical precision per measurement is $\pm 0.10 \%, \pm 0.08 \%$ and $\pm 0.11 \%$ for carbonate

$162 \delta^{13} \mathrm{C}$, carbonate $\delta^{18} \mathrm{O}$, and water $\delta^{18} \mathrm{O}$, respectively.

163 Bulk shells were used for carbonate clumped isotope analyses, using a procedure 164 described previously (Affek and Eiler (2006); Huntington et al. (2009); Zaarur et al. (2011)).

165 Briefly, each shell was sliced along the growth axis. One half was ground to powder using an 166 agate mortar and pestle, providing more than enough powder for all replicate analyses. Aliquots 167 (3-4 mg) of the powdered shell material were digested overnight in $103 \% \mathrm{H}_{3} \mathrm{PO}_{4}$ at $25{ }^{\circ} \mathrm{C} . \mathrm{CO}_{2}$ 168 was extracted cryogenically on a vacuum line and cleaned by passing through a GC column 169 (Supelco Q-Plot, 30m x $0.53 \mathrm{~mm}$ ) at $-20{ }^{\circ} \mathrm{C}$. Measurements were performed using a Thermo 170 MAT253 mass spectrometer. Each measurement consisted of 90 cycles of a sample-standard 171 comparison, with an ion integration time of 20 seconds. Samples were measured in 3-7 replicates 172 (aliquots of powdered shell). $\delta^{18} \mathrm{O}$ and $\delta^{13} \mathrm{C}$ were measured together with $\Delta_{47}$ and are reported 173 using the VPDB scale (using a $25^{\circ} \mathrm{C}$ acid digestion fractionation of $10.25 \%$ for $\delta^{18} \mathrm{O}$; Kim et al., 174 2007a) as determined by a pre-calibrated Oztech $\mathrm{CO}_{2}$ reference working gas, having $\delta^{13} \mathrm{C}$ of $1753.64 \%$ VPDB and $\delta^{18} \mathrm{O}$ of 25.02\% VSMOW, as confirmed by NBS19 IAEA standard analysis.

176 Standardization of $\Delta_{47}$ values was performed using analyses of a set of $\mathrm{CO}_{2}$ gases that 177 were heated at $1000{ }^{\circ} \mathrm{C}$ for 2 hours, resulting in random distribution of the heavy isotopes $178\left(\Delta_{47}=0.027 \%\right.$; Wang et al., 2004), and regular analysis of in-house standards (Carrara marble, 
179 cylinder $\mathrm{CO}_{2}$, and $\mathrm{CO}_{2}$ equilibrated with water at $25{ }^{\circ} \mathrm{C}$ and $50{ }^{\circ} \mathrm{C}$ ) (see Supplementary Material 180 for standardization details). Values are reported in the text using the absolute reference frame 181 (Dennis et al., 2011). Additionally, $\Delta_{47}$ values in the original reference frame (Ghosh et al., 182 2006) are given in Tables 1 and 2 to facilitate comparison with previous studies. We apply the 183 Peirce elimination criterion (Peirce, 1852; Ross, 2003), to the measured data to screen for 184 replicate outliers (replicated measurements of a sample that are significantly different from the 185 mean). Using this criterion we eliminate $3 \%$ of the measurements (5 out of 171). Unless 186 otherwise noted, all reported uncertainties are standard errors based on the number of 187 independent replicated sample aliquots. We reference our samples to the $\Delta_{47}-$ Temperature 188 calibration of Zaarur et al. (2013); the calibration error is $\pm 2{ }^{\circ} \mathrm{C}$. The uncertainties of $\delta^{18} \mathrm{O}_{\text {carbonate }}$ 189 are negligible relative to those of the $\Delta_{47}$ derived temperatures; we therefore calculate the $190 \delta^{18} \mathrm{O}_{\text {water }}$ uncertainties (sections 4.2) based on the $\Delta_{47}$ derived temperature uncertainties.

191 Fossil sample ages were determined by ${ }^{14} \mathrm{C}$ dating at the W.M. Keck Carbon cycle 192 Accelerator Mass Spectrometry Laboratory, UC Irvine (following the methods described by Xu 193 et al., 2007). All reported ages are calibrated using CalPal online program (http://www.calpal194 online.de; Danzeglocke et al., 2012) and we refer to them in the text as ka BP. Shell mineralogy 195 was determined by XRD (at the X-ray Crystallographic Facility, Yale University).

197 3. Results

$198 \quad$ 3.1. ${ }^{14} \mathrm{C}$ dating

199 Fossil samples were dated using radiocarbon measurements of the shells material; 200 measured and calibrated ages are given in Table 2. Calibrated ages for samples of the Gesher 201 Bnot Ya'aqov site range between $\sim 21.7 \pm 0.4 \mathrm{ka} \mathrm{BP}$ and $0.7 \pm 0.01 \mathrm{ka} \mathrm{BP}$. One sample, from the 
202 Musteric terrace, has a ${ }^{14} \mathrm{C}$ age greater than $50 \mathrm{ka} \mathrm{BP}$, which is beyond the radiocarbon detection 203 limit. Fossil samples from the Sea of Galilee, have calibrated ages of $5.6 \pm 0.02$ to $22.5 \pm 0.3 \mathrm{ka}$ 204 BP, and the sample from Gesher Sheikh Hussaein (GSH) has an age of $\sim 40.5 \mathrm{ka} \mathrm{BP}$. A reservoir 205 age of 2 kyrs for the Jordan River was determined through radiocarbon measurements of two modern shells (these specimens were not analyzed for $\Delta_{47}$ ), Consistent with Lev et al. (2007). We use a reservoir age of 750 years for the Sea of Galilee, following Lev et al. (2007). Sea of Galilee samples had been previously dated by Hazan et al. (2005) using radiocarbon measurements of 209 organic material that provide an independent constraint on the reservoir age. For the Hula valley, 210 such materials were not available, but there is no evidence that the source of water and bedrock 211 through which it flows was different in the past (e.g., basaltic versus limestone aquifer). We 212 therefore assume that the reservoir ages in these locations are constant for the time period 213 discussed.

214 The ages of the samples from the Sea of Galilee are consistent with the ${ }^{14} \mathrm{C}$ age measurements of Hazan et al. (2005) for these sites, and are related to the time intervals of 216 relatively high water stands in the lake (Hazan et al., 2005). This implies, that although these 217 samples represent a lake shoreline environment, making them more prone to evaporation than 218 bulk lake water (see section 2.1), the environment captured by these samples is likely broadly 219 representative of lake waters during high stand conditions.

\subsection{Modern Melanopsis shells}

Modern shell data is given in Table 1. Measured water $\delta^{18} \mathrm{O}$ values and temperatures 223 from the different sampling sites range between -4.97 to $+0.50( \pm 0.11 \%)$ and 16 to $25 \pm 0.5{ }^{\circ} \mathrm{C}$, 224 respectively. Shell aragonite isotopic values range between $-1.31 \pm 0.04 \%$ and $-6.94 \pm 0.05 \%$ o 
225 for $\delta^{18} \mathrm{O}$ and between $-3.855 \pm 0.02 \%$ and $-14.17 \pm 0.06 \%$ for $\delta^{13} \mathrm{C} . \Delta_{47}$ values range between $2260.758 \pm 0.012 \%$ and $0.695 \pm 0.011 \%$. As is common in these types of studies, this set of samples 227 does not cover a temperature range that is sufficiently large to create an independent 228 geochemical thermometer calibration. Instead, we use these samples in concert with the existing 229 calibration, to test the applicability of the clumped isotopes thermometer to this material; we 230 compare $\Delta_{47}-T$ relationship of modern shells that grew at known temperatures to the clumped 231 isotopes thermometer calibration of Zaarur et al., (2013). For snail growth temperatures, we use 232 our measured temperatures for spring grown shells, as spring water is expected to be constant 233 year round due to the long residence time in the bedrock that allows for thermal equilibrium. The 234 Sea of Galilee, has a large seasonal temperature variability (15-29 $\left.{ }^{\circ} \mathrm{C}\right)$, hence, for this location 235 we use the mean annual temperature. Within error, modern Melanopsis shells are consistent with 236 the Zaarur et al., (2013) $\Delta_{47}-T$ calibration (Figure 2a), and we therefore conclude that this 237 calibration can be used for fossil shells. Note that none of our shells, either modern or fossil, is 238 likely to have grown at a temperature that is low enough to suffer from large uncertainty due to 239 the choice of calibration (e.g., Zaarur et al., 2013 versus Henkes et al., 2013).

240 To test for variability among individual shells of the same species in the same location 241 and over time, we compare 3 specimens from Gesher Bnot Ya'aqov (GBY) that were collected 242 together in 2009, to a specimen collected (and therefore living) 6 years earlier at the same 243 location (GBY 2003), and to a specimen collected in 2009 at Gesher Hapkak (GHP) 4.5 km 244 upstream of Gesher B'not Ya'aqov (GBY). Four of the five samples have $\Delta_{47}$ values that are 245 indistinguishable from each other $(0.702 \pm 0.011 \%$ o to $0.709 \pm 0.015 \%$, corresponding to $24-25$ $246{ }^{\circ} \mathrm{C}$ ) and one sample, GBY-a, has a value of $0.695 \pm 0.011 \%$ (corresponding to $27{ }^{\circ} \mathrm{C}$ ). Even 247 though this difference is within the average sample measurement uncertainty $( \pm 0.01 \%)$, it is 
248 flagged as an outlier by the Peirce elimination criteria. No significant difference in $\delta^{18} \mathrm{O}$ is 249 observed, however, between these specimens.

250 To examine the potential for bias due to seasonal preference in shell secretion, we 251 conducted high-resolution $\delta^{18} \mathrm{O}$ analyses in individual shells. $\delta^{18} \mathrm{O}$ values of the sample from the 252 Sea of Galilee $(M$. costata $)$ are high $(-0.80 \pm 0.55 \%)$ and show a strong seasonal variability; the 253 shell $\delta^{18} \mathrm{O}$ seasonality encompasses 2 annual cycles (Figure 2$) . \delta^{18} \mathrm{O}$ values of a shell $(M$. 254 costata) from the Jordan River are ${ }^{18} \mathrm{O}$-depleted relative to the Sea of Galilee $(-7.0 \pm 0.5 \%)$, also 255 showing cyclic seasonal variability (Figure 2$). \delta^{18} \mathrm{O}$ values of a shell (M. buccinoidea) from the 256 Dan Spring are fairly constant with $\delta^{18} \mathrm{O}$ values of $-6.5 \pm 0.3 \%$, showing no evidence of seasonal 257 variability; this is consistent with the stable spring water temperature and $\delta^{18} \mathrm{O}$ composition 258 (Figure 2). Shells from different habitats exhibited different patterns that reflect the 259 environmental variability they were exposed to. The cyclical nature of the $\delta^{18} \mathrm{O}$ signal suggests 260 year round growth and that individual gastropod lives for about 2 years, such that bulk shell 261 composition may be interpreted as reflecting mean annual conditions. We cannot exclude the 262 possibility of a minor seasonal growth preference, in particular as a shell that lived $\sim 2$ years may 263 have been collected after less (or slightly more) than a full growth cycle.

264 Shell carbon isotopes have been suggested to be in equilibrium with dissolved inorganic 265 carbon (DIC) of the habitat water (Lev et al., 2007). Shells $\delta^{13} \mathrm{C}$ values from most sites range 266 between -8.1 and $-9.3 \%$. The DIC in these locations is dominated by the association of the water 267 with a carbonate bedrock. The shell from the Gonen Spring, in which water is associated with 268 basaltic rocks, has a lower $\delta^{13} \mathrm{C}$ value (-14.2\%o). Geinosar Beach, at the Sea of Galilee, has a 269 higher $\delta^{13} \mathrm{C}$ value (-3.9\%o) that is likely associated with the substantial ${ }^{12} \mathrm{C}$ uptake by primary 270 producers in the lake (Dubowski et al., 2003). The shell from Ein Tamar has a relatively high 
$271 \delta^{13} \mathrm{C}$ value $(-5.3 \%)$ that could reflect the local bedrock or the effect of primary productivity

272 within the small pool where the spring water accumulate. $\delta^{13} \mathrm{C}$ values are given in Table 1 but 273 are not discussed further.

\section{$275 \quad 3.3$ Last glacial-Holocene shells}

Data of fossil shells are given in Table 2. The oxygen isotopic composition of Melanopsis

277 shells from the Hula Valley range from -4.1 to $-6.4 \%$, and in the Sea of Galilee from -4.8 to $278-0.5 \%$. $\Delta_{47}$ values of the Hula Valley indicate that water temperature in the late glacial (21.7$27917.6 \mathrm{ka} \mathrm{BP}$ ) was $23 \pm 2{ }^{\circ} \mathrm{C}$; temperatures then increase to $28 \pm 1{ }^{\circ} \mathrm{C}$ in the early to mid-Holocene 280 (10.2-5.9 ka BP). Two early Holocene (12.1 and $10.0 \mathrm{ka}$ BP) Hula Valley bivalves have $\Delta_{47}$ 281 values $(0.686 \%$ and $0.705 \%$ o $)$ that agree with those of the Melanopsis shells, providing further 282 support for the consistency of these fresh water mollusks with the clumped isotope thermometer 283 calibration. The temperatures derived from $\Delta_{47}$ in the Sea of Galilee are $21 \pm 3{ }^{\circ} \mathrm{C}$ for the late 284 glacial (22.5-22.0 ka BP) and $24 \pm 4{ }^{\circ} \mathrm{C}$ in early-mid Holocene (7.6-5.6 ka BP). Sea of Galilee 285 and Hula Valley temperatures are mostly consistent with each other; the regional temperatures 286 derived from combining the data from the two water bodies are: $22 \pm 2{ }^{\circ} \mathrm{C}$ for late glacial (22.5$28717.6 \mathrm{ka} \mathrm{BP}), 27 \pm 2{ }^{\circ} \mathrm{C}$ in the early to mid-Holocene (12.1-5.9 ka BP). One late Holocene (0.7 ka 288 BP) sample has a temperature of $22 \pm 2{ }^{\circ} \mathrm{C}$.

289 One sample dated to $\sim 40.5 \mathrm{ka}$ BP was available from the Central Jordan River, at Gesher 290 Sheikh Hussein, $\sim 25 \mathrm{~km}$ south of the Sea of Galilee. This location is at the southern outlet of the 291 Sea of Galilee and thus, is expected to be closely related in temperature to Sea of Galilee water, 292 with perhaps a slight enrichment of $\delta^{18} \mathrm{O}$ due to additional evaporation. One fossil shell was 293 collected from the Mousterian terrace at the Gesher Bnot Ya'aqov archaeological site; 
294 radiocarbon measurements suggest that it is older than of $50 \mathrm{ka} \mathrm{BP}$, beyond the range of 295 radiocarbon dating. Due to the lack of continuity and age uncertainty of these samples, we report 296 the data in Table 2 but do not discuss the data further.

\section{Discussion}

Paleoclimate in the Eastern Mediterranean-Levant region has been studied in the marine

300

\subsection{Modern shells - seasonality and habitat}

High-resolution $\delta^{18} \mathrm{O}$ profiles of modern shells vary amongst the three sampled sites in a way that reflects the expected variability of water isotopic composition at the different types of habitats. The shell from Dan Spring has low $\delta^{18} \mathrm{O}$ values and only little variability. This is 
317 expected as the Dan Spring is fed by ${ }^{18} \mathrm{O}$-depleted snow melt with a long residence time within

318 the bedrock, yielding a stable temperature and water $\delta^{18} \mathrm{O}$ composition which are not affected by

319 individual precipitation events or by seasonality. Melanopsis shells were collected near the

320 spring outlet in a shaded area, minimizing the possibility of temporal variations in $\delta^{18} \mathrm{O}$ due to

321 evaporation.

322 The Jordan River is fed by Dan, Banias, and Hatzbani springs and is therefore expected

323 to reflect a combination of these waters. The high-resolution $\delta^{18} \mathrm{O}$ of a shell from Gesher Bnot

324 Ya'aqov has on average similar $\delta^{18} \mathrm{O}$ values to that of the Dan Spring but exhibits some cyclical

325 variations that likely reflect seasonal changes in evaporation from the Jordan River. The

326 sampling site at Gesher Bnot Ya'aqov is not fully shaded and specimens were collected in

327 shallow water. Temporal variations in temperature and $\delta^{18} \mathrm{O}$ are expected due to the relative

328 contribution of the several water sources, local surface water evaporation, and warming due to 329 direct exposure to solar heating.

330 The Jordan River is a major water source to the Sea of Galilee (50\%). Lake waters,

331 however, are strongly affected by evaporation and the modern setting is practically that of a

332 terminal lake (due to a dam at the main outlet). The shell from the Sea of Galilee has $\delta^{18} \mathrm{O}$ values

333 that are higher than Gesher B'not Ya'aqov and Dan Spring, and exhibit a strong seasonal signal.

334 As typical for either terminal or flow-through lakes, the Sea of Galilee $\delta^{18} \mathrm{O}$ water values are 335 higher than its water source due to evaporation from the lake surface.

336 The high-resolution isotopic profiles thus reflect the type of seasonality characteristic of 337 each hydrological setting and the full cycles suggest that Melanopsis shells grow year round. As 338 clumped isotope measurements require a bulk shell analysis, the continuous secretion of shell 339 material year round suggests that $\Delta_{47}$ would reflect mean annual conditions. 


\subsection{Clumped isotopes in modern Melanopsis}

$\Delta_{47}$ values of modern Melanopsis shells grown at known temperatures are consistent,

343 within error, with the carbonate clumped isotope thermometer calibration (Zaarur et al., 2013).

344 The variability observed in Melanopsis shells around the thermometer calibration is similar to

345 the variability of other biogenic carbonates (see figure 4 of Zaarur et al., 2013). Five specimens

346 from the same location (GBY a,b,c, GBY 2003 and GHP), have $\Delta_{47}$ values that are

347 indistinguishable from one another, indicating that the snails reliably record the same conditions

348 and have similar shell growth patterns. No difference in $\Delta_{47}$ is observed between the two species,

349 M.costata and M. buccinoidea.

350 We combine the temperatures derived from $\Delta_{47}$ with the $\delta^{18} \mathrm{O}$ of the carbonate shell to

351 calculate the isotopic composition of the water in which the shells grew, using the Kim et al.

352 (2007b) aragonite-water fractionation calibration (Table 1). Calculated $\delta^{18} \mathrm{O}_{\text {water }}$ values are

353 generally consistent with measured $\delta^{18} \mathrm{O}_{\text {water }}$ at the collection sites (Table 1). Isotopic

354 fractionations $(\alpha)$ vary somewhat between the two species, with M.costata exhibiting

355 fractionations that are closer to the Kim et al. (2007b) calibration and M. buccinoidea exhibit

356 more variability and an average offset of $\sim 1.2 \pm 0.6 \%$ from the Kim et al. (2007b) calibration

357 (Figure $3 b$ ). The difference in $\delta^{18} \mathrm{O}$ between the two species could result from differences in

358 growth rates that effect the $\delta^{18} \mathrm{O}$ but not $\Delta_{47}$ (Affek and Zaarur, 2014; Kluge et al., 2014; Tang et

359 al., 2014), or perhaps from a vital effect associated with differences in $\delta^{18} \mathrm{O}_{\text {water }}$ between the

360 calcifying fluid and environmental water. While natural variability, measurement uncertainty,

361 and the small size of our data set prevent us from creating an independent calibration for

362 Melanopsis shells, the observations are sufficient to indicate that temperatures derived from 
363 clumped isotopes can be used to derive water $\delta^{18} \mathrm{O}_{\text {water }}$ with an estimated species specific oxygen

364 isotope fractionation. Due to the apparent ${ }^{18} \mathrm{O}$-depletion relative to Kim et al. (2007b), $1.2 \%$ is 365 added to $\delta^{18} \mathrm{O}_{\text {water }}$ calculated from fossil M. buccinoidea albeit with a relatively large uncertainty.

\subsection{Late Glacial to Holocene temperatures}

The amplitude of the late Glacial to Holocene warming we observe is of $5^{\circ} \mathrm{C}$ increase between the late glacial and early- to mid-Holocene, consistent with Mediterranean Sea surface temperatures, as derived from alkenone unsaturation (Almogi-Labin et al., 2009; Martrat et al., 371 2004), and with Soreq Cave speleothems (Affek et al., 2008; Affek et al., 2014). In absolute

372 terms, however, the temperatures we observe are $7-10^{\circ} \mathrm{C}$ warmer than either the Mediterranean

373 Sea surface or Soreq Cave. Similar temperature difference is also observed at present-day and is 374 related to the different geographic setting, mostly elevation. Whereas Soreq Cave is at $400 \mathrm{~m}$ asl 375 with mean annual temperatures of $18-19^{\circ} \mathrm{C}$, the Sea of Galilee is at $\sim 212 \mathrm{~m}$ bsl, with a modern 376 mean annual temperature of $\sim 24{ }^{\circ} \mathrm{C}$. A temperature gap similar to that in modern-day thus has 377 been present also at the end of the last glacial period.

A glacial-interglacial warming of $5{ }^{\circ} \mathrm{C}$ is larger than that in the eastern tropical Atlantic

379 (3.5 ${ }^{\circ} \mathrm{C}$; Schneider et al., 1995). The larger amplitude is explained by the semi-enclosed basin 380 effect of the Mediterranean Sea and the reduced moderating effect of the Atlantic Ocean during 381 the glacial, compared to the Holocene (Almogi-Labin et al., 2009). Similar to the amplification 382 of the Mediterranean Sea relative to the Atlantic Ocean, the amplitude of temperature change 383 observed in our data can also be explained by an amplification effect of terrestrial surface water. 384 Alternatively, higher temperatures may be the result of the Melanopsis recording lake waters that 385 in some cases are warmer than air temperatures (Hren and Sheldon, 2012). In a survey of 
multiple lakes, Hren and Sheldon (2012) noted that the mean annual temperature of lake surface water is typically higher than the respective mean annual air temperature; the effect being most pronounced in cold regions, and is small when air temperature is above $10{ }^{\circ} \mathrm{C}$. This effect is 389 likely insignificant in the relatively warm Levant, and may only be somewhat relevant in the 390 Glacial. If so, the expectation would be a reduced glacial-interglacial temperature difference, 391 contrary to our observations.

\subsection{Paleohydrology}

Changes in the isotopic composition of water can provide information about the hydrological evolution of the region. The temperatures derived from $\Delta_{47}$ are combined with the $\delta^{18} \mathrm{O}$ of the aragonitic shells to calculate the isotopic composition of the water in which the snails 397 grew (Figure 4). $\delta^{18} \mathrm{O}_{\text {water }}$ values of Hula Valley water are $\sim-5.0 \pm 0.3 \%$ in the late Glacial and 398 increase to $\sim-2.9 \pm 0.8 \%$ in the early to mid-Holocene. Sea of Galilee $\delta^{18} \mathrm{O}_{\text {water }}$ values are $3992.6 \pm .7 \%$ in the late Glacial and are much more ${ }^{18} \mathrm{O}$-enriched, up to $+1.5 \%$, in the early to mid400 Holocene. Two main features are apparent in the isotopic evolution of the two water bodies. 401 First, unlike the uniformity of water temperatures in the two locations, but similar to the modern402 day water composition, Sea of Galilee waters are ${ }^{18} \mathrm{O}$-enriched relative to the Hula waters. 403 Considering the coarse time resolution, the difference is fairly constant over time, at $\sim 4 \pm 1 \%$, 404 reflecting evaporative enrichment of the lake relative to the incoming water. Second, the $\delta^{18} \mathrm{O}_{\text {water }}$ 405 values in both locations are lower during the late Glacial relative to the Holocene. This is contrary to what would be expected if these waters followed the global trends in the oceans or

407 the regional trends of the Mediterranean Sea and associated rainfall, in which glacial $\delta^{18} \mathrm{O}_{\text {water }}$ 408 values are higher than those in the Holocene, as a result of continental ice buildup. 


\subsection{1. $\delta^{18} \mathrm{O}_{\text {water }}$ of Hula and Sea of Galilee}

In the geological past, our sampling location at Gesher Bnot Ya'akov, may have resembled its modern hydrological setting of the slow flowing Jordan River; alternatively, it may

413 have been a shallow lake or a swampy environment, similar to the early $20^{\text {th }}$ century Lake Hula.

414 Irrespective of its specific form, however, it has been a main water source to the Sea of Galilee 415 (Horowitz, 1978). In the modern setting, the Sea of Galilee is $\sim 5 \%$ more ${ }^{18} \mathrm{O}$-enriched relative to 416 the Hula water. This enrichment results from it being downstream of the Hula Valley and is due 417 to a high evaporation flux from the lake surface. The damming of the lake in 1932 converted the 418 Sea of Galilee from a flow-through to a terminal lake with enhanced evaporation $(\sim 35 \%$ of 419 inflowing waters; Gvirtzman, 2002). Similarly, our data suggest that from the late Glacial 420 through the Holocene, Sea of Galilee waters were $4 \pm 1 \%$, more enriched relative to the Hula 421 waters. The roughly constant difference in $\delta^{18} \mathrm{O}_{\text {water }}$ between the two implies that their 422 hydrological relationship had remained constant, with the glacial-interglacial increase in 423 temperature playing only a minor role in enhancing evaporation of the Sea of Galilee relative to 424 the Hula waters.

425

426 4.4.2. The direction of isotopic change

427 In comparing to global and regional glacial-interglacial $\delta^{18} \mathrm{O}$ trends, our record shows a 428 reverse signal with an isotopically depleted glacial relative to post-glacial. When considering 429 potential causes for the reverse trend in $\delta^{18} \mathrm{O}_{\text {water }}$ in our records, it is important to consider local 430 hydrology and the different processes that can affect the $\delta^{18} \mathrm{O}$ of the water. The Mediterranean 431 Sea is the main source of moisture in this region today and was so also during glacial times, in 
432 spite of a southward shift in the shoreline and storm trajectories, due to lower sea levels (Enzel et

433 al., 2008). This is evident from the general shape of $\delta^{18} \mathrm{O}$ trends in several regional terrestrial 434 records that follow the trends and magnitude of Mediterranean Sea water (e.g., Bar-Matthews et 435 al., 2003; Frumkin et al., 1999; Kolodny et al., 2005).

437 2003; Bar-Matthews et al., 2000), and lake (Kolodny et al., 2005) records in the region are 438 consistent with the global trends of Glacial-Interglacial transition, with an amplification that is 439 characteristic of the semi-enclosed Mediterranean basin. Kolodny et al. (2005) showed that for 440 the past $\sim 70 \mathrm{ka}$ the differences in $\delta^{18} \mathrm{O}$ between Mediterranean Sea foraminifera, Soreq Cave 441 speleothems, and Lake Lisan sediments are constant leading to the conclusion that the terrestrial 442 records are governed by the changes in Mediterranean Sea water that are transcribed into rainfall 443 composition, albeit with local modifications. Furthermore, the $\delta^{18} \mathrm{O}_{\text {carbonate }}$ record of the 444 Yammoûneh Lake, in Lebanon (in the northern Levant) exhibits an isotopic trend similar to the 445 global and regional Glacial-Interglacial changes, with late Glacial values being $\sim 2 \%$ more ${ }^{18} \mathrm{O}$ 446 enriched than the Holocene (Develle et al., 2010). Our record is unique at displaying an opposite 447 trend, namely of increasing $\delta^{18} \mathrm{O}$ values through the Glacial to Holocene transition in both $448 \delta^{18} \mathrm{O}_{\text {carbonate }}$ and calculated $\delta^{18} \mathrm{O}_{\text {water }}$; this is observed more strongly in the Sea of Galilee record 449 (Figure 4). Note that when examining the Glacial to Holocene transition in $\delta^{18} \mathrm{O}_{\text {carbonate, }}$, the 450 change is a combination of variations in both temperature and $\delta^{18} \mathrm{O}_{\text {water }} \cdot \Delta_{47}$-derived temperatures 451 enable the isolation of the $\delta^{18} \mathrm{O}_{\text {water }}$ component and in our case do not eliminate the opposite 452 trend observed in the waters.

Paleo- $\delta^{18} \mathrm{O}_{\text {water }}$ values of both sites in this study follow the same trend as the $\delta^{18} \mathrm{O}_{\text {carbonate, }}$ 454 with Holocene waters that are isotopically enriched relative to the late Glacial waters (as 
455 determined by a student-t test; Figure 4). Develle et al. (2010) used a compilation of literature 456 temperature estimates to assess $\delta^{18} \mathrm{O}_{\text {water }}$ composition in the Yammoûneh Lake, resulting in ${ }^{18} \mathrm{O}$ 457 enriched Holocene water relative to the late Glacial, similar to our observations. In contrast, $458 \delta^{18} \mathrm{O}_{\text {water }}$ in Soreq Cave has Holocene waters that are ${ }^{18} \mathrm{O}$-depleted relative to the late Glacial, but 459 reflecting an attenuation of the trend observed in $\delta^{18} \mathrm{O}_{\text {carbonate }}$ (Affek et al., 2008). A $\delta^{18} \mathrm{O}_{\text {water }}$ 460 reconstruction of Soreq Cave waters, as estimated by Develle et al. (2010), suggests Holocene 461 values that are similar to the late Glacial (excluding the time period of the last Sapropel event) 462 implying that the observed signal in the speleothem carbonate is driven predominantly by 463 temperature changes rather than a change in the isotopic composition of the water.

As the Mediterranean Sea has been the main source of moisture throughout this time 465 period in all 3 locations, any scenario explaining the opposite change in $\delta^{18} \mathrm{O}_{\text {water }}$ observed in our 466 record must reside within the local hydrological setting. We therefore suggest that the late 467 Glacial-Holocene $\delta^{18} \mathrm{O}_{\text {water }}$ shift is the result of a change in the form of precipitation and/or in 468 evaporation fluxes.

469 Today, local precipitation in the Jordan River (which flows through the Hula Valley and 470 into the Sea of Galilee) and in the Soreq Cave area is almost exclusively in the form of rain. 471 Most of the water inflow into the Jordan River, however, is sourced in several springs that are 472 fed by snowmelt from mountains to the north. Given the glacial temperatures, local precipitation 473 was probably still predominantly in the form of rain but the relative contribution of snowmelt to 474 the tributaries flowing into the Jordan River may have been larger. Snow is typically ${ }^{18} \mathrm{O}-$

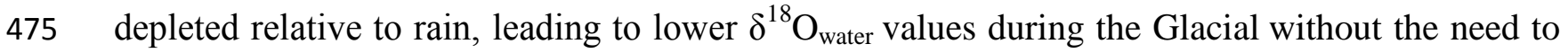
476 invoke a change in either precipitation amount or moisture source. As temperatures increased in 477 the Holocene, rain is likely to have become more dominant in the river inflow, such that the 
478 reversed signal observed between the late Glacial and Holocene waters could reflect a transition

479 from a snow dominated system to the snow-rain mixture observed today.

This scenario would also explain the Yammoûneh Lake $\delta^{18} \mathrm{O}_{\text {water }}$ record that exhibits late

481 Glacial values that are $3 \%$ o lower than Holocene and modern waters (Develle et al., 2010).

482 Develle et al. (2010) interpret this reverse signal as reflecting one of several alternatives: an

483 increased "continental effect" due to lower sea levels, increased amounts of rain during the late

484 Glacial with the "amount effect" controlling the isotopic signal, or a steeper glacial lapse rate. A

485 steeper lapse rate would result in colder precipitation and hence an increased proportion of 486 precipitation in the form of snow, consistent with our interpretation. The Soreq Cave water input

487 is expected to have been in the form of rain with no significant snow input also in the Glacial, as

488 it is located further south and at low elevation; its water $\delta^{18} \mathrm{O}$ values therefore follow the 489 Mediterranean Sea and global $\delta^{18} \mathrm{O}$ trends. A speleothem record from Mizpe Shelagim Cave, on 490 Mount Hermon, the Southern end of the trans-Lebanon mountain range (Figure 1) and a source 491 of snowmelt in the region, is similar to the Soreq Cave record (Ayalon et al., 2013). However, 492 speleothems in this cave were not deposited during the LGM suggesting sub-freezing 493 temperatures that again support a snow dominated system and increased snowmelt contribution 494 at somewhat lower elevation in the Jordan River watershed. Speleothem data in Mizpe Shelagim 495 Cave are available shortly after the LGM ( 18 ka), such that the direction of post LGM isotopic 496 change is observed, and is similar to that in Soreq Cave. This similarity is not surprising as the 497 form of precipitation in the high elevation Mizpe Shelagim Cave is not expected to have shifted 498 throughout this time period, and has been snow dominated both today and in the past.

A sensitivity test suggests that at least $10 \%$ decrease in snow contribution during the 500 Holocene relative to the late Glacial is required to yield the observed reversed $\delta^{18} \mathrm{O}_{\text {water }}$ trend. We 
501 use the isotopic composition of modern-day precipitation on Mount Hermon (at Mitzpe

502 Shelagim; Ayalon et al. 2013) to estimate the modern mass balance of water sources in the 503 region. Precipitation $\delta^{18} \mathrm{O}$ values range between $-5 \%$ and $-10.5 \%$ for the time period of $02 / 2001$ $504-04 / 2009$; we infer these to be the rain and snow end-members of local precipitation. The 505 balance is then derived by comparing these end-member values with the modern-day Dan spring 506 water, which is fed directly from Mt. Hermon precipitation, and is the main tributary to the 507 Jordan River.

The Dan Spring, with $\delta^{18} \mathrm{O}$ value of $-6.9 \%$, reflects an input of approximately $65 \%$ rain 509 and $35 \%$ snow. Average modern Upper Jordan River waters have a $\delta^{18} \mathrm{O}$ value of $-4.8 \%$. The 510 Jordan River water $\delta^{18} \mathrm{O}$ is similar or slightly more ${ }^{18} \mathrm{O}$-enriched than rainwater, and significantly 511 more enriched than snow. The enrichment relative to the Dan spring must therefore indicate 512 evaporative enrichment within the river system. To estimate the relative rain versus snow 513 contribution during the glacial period, we assume the same sea-to-land isotopic difference as 514 today (following Almogi-Labin et al, 2009), with marine carbonates being 2.5\%o more enriched 515 during the late Glacial (Bar-Matthews et al, 2003). If the trend in marine carbonates is 516 transcribed into an equivalent trend in the isotopic composition of precipitation (both rain and 517 snow), resulting in estimated rain and snow values of $-2.5 \%$ and $-8 \%$, then the same relative 518 contribution of snow and rain as modern would result in spring water of $~-4.4 \%$. Mean water $519 \delta^{18} \mathrm{O}$ value in the Jordan River between $17.6-21.7 \mathrm{ka} \mathrm{BP}$, however, is $-5.0 \%$, similar to the 520 modern-day value, and similar or lower than the assumed spring waters. For river $\delta^{18} \mathrm{O}$ value to 521 have remained constant, it had to have been fed by a larger relative contribution of ${ }^{18} \mathrm{O}$-depleted 522 water from snowmelt. With no evaporative enrichment between spring and river waters, paleo523 river waters of $-5.0 \%$ thus require a minimum of $10 \%$ increase in snow contribution. Lower 
524 glacial temperatures would have reduced the degree of water evaporation relative to today, but

525 no evaporation at all is unlikely, such that the snowmelt contribution is likely to have been even

526 higher.

The approximately constant difference between Hula and Sea of Galilee waters $\delta^{18} \mathrm{O}$

528 values suggests that the Glacial to Holocene warming had a minimal effect on the evaporation

529 flux out of the Sea of Galilee, relative to the incoming water from the Jordan River. The reversed

530 Glacial-Interglacial $\delta^{18} \mathrm{O}_{\text {water }}$ signal could, however, reflect the evolution of regional hydrology,

531 with surface waters being more evaporated during the Holocene relative to the Glacial in both

532 the Sea of Galilee and the Jordan River that feeds it.

533 Our Sea of Galilee samples are dated to time periods of relatively high water levels in the

534 Sea of Galilee, during the last Glacial MIS2 and Holocene, although they all postdate the 535 separation of Lake Lisan and Sea of Galilee, and hence represent a small lake. Evaporation from 536 the small and shallow Sea of Galilee would result in further isotopic enrichment. Whereas a 537 minor shift in precipitation form can easily explain the reverse signal in Glacial-Holocene (and 538 modern) $\delta^{18} \mathrm{O}_{\text {water, }}$ increased evaporation from a smaller lake may serve to amplify the signal 539 generated by a shift in precipitation form, and can also provide an alternative explanation to the 540 observed isotopic trend.

\section{Summary}

In summary, our $\delta^{18} \mathrm{O}$ and $\Delta_{47}$ measurements of modern Melanopsis shells suggests that

544 the clumped isotope thermometer calibration is relevant to these materials, and that Melanopsis

545 shells can be used in the fossil record to reconstruct terrestrial temperatures as well as paleo-

546 water $\delta^{18} \mathrm{O}$. We find that the amplitude of temperature change from the late Glacial to the present 
547 is consistent with other regional records. Contrary to global and regional trends, however, our

548 Glacial to Holocene $\delta^{18} \mathrm{O}_{\text {water }}$ trend exhibit an increase in values, with an isotopically enriched

549 Holocene relative to the Glacial. We interpret this reverse signal to represent a transition from a

550 snowmelt to a rain dominated system.

551

552

553 Acknowledgments

554 We thank Einot Tzukim and Ein Gedi Israel National Parks for providing water and shell 555 materials; Eric Lazo-Wasem and Lourdes Rojas from the Yale Peabody Museum of Natural 556 History, Henk Mienes from Steinhardt National Collections of Natural History Department of 557 Zoology Tel Aviv University and Adam Baldinger from the Harvard University Museum of 558 Comparative Zoology for assistance in snail species identification. We thank Gerard Olack, 559 Dominic Colosi, Glendon Husinger of the Earth System Center for Stable Isotope Studies for 560 technical support. The work was supported by the National Science Foundation Grant NSF561 EAR-0842482 to Hagit Affek.

562 


\section{References}

564 Affek, H.P., Bar-Matthews, M., Ayalon, A., Matthews, A., Eiler, J.M., 2008. Glacial/interglacial

565 temperature variations in Soreq cave speleothems as recorded by 'clumped isotope' thermometry.

566 Geochimica et Cosmochimica Acta 72, 5351-5360.

567 Affek, H.P., Eiler, J.M., 2006. Abundance of mass $47 \mathrm{CO}_{2}$ in urban air, car exhaust, and human breath. Geochimica et Cosmochimica Acta 70, 1-12.

569

570

571

572

573

574

575

576

577

578

579

580

581

582

583

584

585

586

587

588

Affek, H.P., Matthews, A., Ayalon, A., Bar-Matthews, M., Burstyn, Y., Zaarur, S., Zilberman, T., 2014. Accounting for kinetic isotope effects in Soreq Cave (Israel) spleothems. Geochimica et Cosmochimica Acta 143, 303-318.

Affek, H.P., Zaarur, S., 2014. Kinetic isotope effect in $\mathrm{CO}_{2}$ degassing: insight from clumped and oxygen isotopes in laboratory precipitation experiments. Geochimica et Cosmochimica Acta 143, 319-330.

Almogi-Labin, A., Bar-Matthews, M., Shriki, D., Kolosovsky, E., Paterne, M., Schilman, B., Ayalon, A., Aizenshtat, Z., Matthews, A., 2009. Climatic variability during the last similar to 90 $\mathrm{ka}$ of the southern and northern Levantine Basin as evident from marine records and speleothems. Quaternary Science Reviews 28, 2882-2896.

Ayalon, A., Bar-Matthews, M., Frumkin, A., Matthews, A., 2013. Last Glacial warm events on Mount Hermon: the southern extension of the Alpine karst range of the east Mediterranean. Quaternary Science Reviews 59, 43-56.

Bar-Matthews, M., Ayalon, A., Gilmour, M., Matthews, A., Hawkesworth, C.J., 2003. Sea-land oxygen isotopic relationships from planktonic foraminifera and speleothems in the Eastern Mediterranean region and their implication for paleorainfall during interglacial intervals. Geochimica Et Cosmochimica Acta 67, 3181-3199.

Bar-Matthews, M., Ayalon, A., Kaufman, A., 2000. Timing and hydrological conditions of Sapropel events in the Eastern Mediterranean, as evident from speleothems, Soreq cave, Israel. Chemical Geology 169, 145-156. 
589 Bar-Yosef, O., Belfer-Cohen, A., 2013. Following Pleistocene road signs of human dispersals 590 across Eurasia. Quaternary International 285, 30-43.

591 Bartov, Y., Stein, M., Enzel, Y., Agnon, A., Reches, Z., 2002. Lake levels and sequence 592 stratigraphy of Lake Lisan, the late Pleistocene precursor of the Dead Sea. Quaternary Research 593 57, 9-21.

594 Begin, Z.B., Stein, M., Katz, A., Machlus, M., Rosenfeld, A., Buchbinder, B., Bartov, Y., 2004. 595 Southward migration of rain tracks during the last glacial, revealed by salinity gradient in Lake 596 Lisan (Dead Sea rift). Quaternary Science Reviews 23, 1627-1636.

597 Bourguignat, J., 1853. Catalogue raisonné des mollusques terrestres et fluviatiles recueillis par 598 M. F. de Saulcy pendant son voyage en Orient., Paris: Gide \& Baudry.

599 Cheddadi, R., Rossignolstrick, M., 1995. Eastern Mediterranean Quaternary paleoclimates from 600 pollen and isotope records of marine cores in the Nile cone area. Paleoceanography 10, 291-300.

601 Danzeglocke, U., Jöris, O., Weninger, B., 2012. CalPal-2007 ${ }^{\text {online }}$ (online version), CalPal$6022007^{\text {online }} \cdot$ http://www.calpal-online.de/.

603 Dayan, U., 1986. Climatology of back trajectories from Israel based on synoptic analysis. Journal 604 of Climate and Applied Meteorology 25, 591-595.

605 Dennis, K.J., Affek, H.P., Passey, B.H., Schrag, D.P., Eiler, J.M., 2011. Defining an absolute 606 reference frame for 'clumped' isotope studies of $\mathrm{CO}_{2}$. Geochimica Et Cosmochimica Acta 75, $607 \quad 7117-7131$.

608 Develle, A.-L., Herreros, J., Vidal, L., Sursock, A., Gasse, F., 2010. Controlling factors on a 609 paleo-lake oxygen isotope record (Yammouneh, Lebanon) since the Last Glacial Maximum. 610 Quaternary Science Reviews 29, 865-886.

611 Dubowski, Y., Erez, J., Stiller, M., 2003. Isotopic paleolimnology of Lake Kinneret. Limnology 612 and Oceanography 48, 68-78. 
613 Enzel, Y., Arnit, R., Dayan, U., Crouvi, O., Kahana, R., Ziv, B., Sharon, D., 2008. The climatic 614 and physiographic controls of the eastern Mediterranean over the late Pleistocene climates in the southern Levant and its neighboring deserts. Global and Planetary Change 60, 165-192.

616 Frumkin, A., Bar-Yosef, O., Schwarcz, H.P., 2011. Possible paleohydrologic and paleoclimatic 617 effects on hominin migration and occupation of the Levantine Middle Paleolithic. Journal of 618 Human Evolution 60, 437-451.

619 Frumkin, A., Ford, D.C., Schwarcz, H.P., 1999. Continental oxygen isotopic record of the last 620170,000 years in Jerusalem. Quaternary Research 51, 317-327.

621 Gat, J.R., 1995. Stable Isotopes of Fresh and Saline Lakes, in: Lerman, A., Imboden, D.M., Gat, 622 J.R. (Eds.), Physics and Chemistry of Lakes. Springer Berlin Heidelberg, pp. 139-165.

623 Ghosh, P., Adkins, J., Affek, H., Balta, B., Guo, W.F., Schauble, E.A., Schrag, D., Eller, J.M., 624 2006. ${ }^{13} \mathrm{C}^{18} \mathrm{O}$ bonds in carbonate minerals: A new kind of paleothermometer. Geochimica Et 625 Cosmochimica Acta 70, 1439-1456.

626 Gvirtzman, H., 2002. Israel water resources. Chapters in Hydrology and Environmental 627 Sciences. Yad Ben-Zvi Press, Jerusalem.

628 Hazan, N., Stein, M., Agnon, A., Marco, S., Nadel, D., Negendank, J.F.W., Schwab, M.J., Neev, 629 D., 2005. The late quaternary limnological history of Lake Kinneret (Sea of Galilee), Israel. 630 Quaternary Research 63, 60-77.

631 Henkes, G.A., Passey, B.H., Wanamaker, A.D., Jr., Grossman, E.L., Ambrose, W.G., Jr., Carroll, 632 M.L., 2013. Carbonate clumped isotope compositions of modern marine mollusk and brachiopod 633 shells. Geochimica Et Cosmochimica Acta 106, 307-325.

634 Horowitz, A., 1978. The Quaternary evolution of the Jordan Valley, in: Serruya, C. (Ed.), Lake 635 Kinnerat, Monografiae Biologicae.

636 Hren, M.T., Sheldon, N.D., 2012. Temporal variations in lake water temperature: 637 Paleoenvironmental implications of lake carbonate $\delta^{18} \mathrm{O}$ and temperature records. Earth and 638 Planetary Science Letters 337, 77-84. 
651

652

Huntington, K.W., Eiler, J.M., Affek, H.P., Guo, W., Bonifacie, M., Yeung, L.Y., Thiagarajan, N., Passey, B., Tripati, A., Daeron, M., Came, R., 2009. Methods and limitations of 'clumped' $\mathrm{CO}_{2}$ isotope $\Delta_{47}$ analysis by gas-source isotope ratio mass spectrometry. Journal of Mass Spectrometry 44, 1318-1329.

Kim, S.-T., Mucci, A., Taylor, B.E., 2007a. Phosphoric acid fractionation factors for calcite and aragonite between 25 and 75 degrees C: Revisited. Chemical Geology 246, 135-146.

Kim, S.T., O'Neil, J.R., Hillaire-Marcel, C., Mucci, A., 2007b. Oxygen isotope fractionation between synthetic aragonite and water: Influence of temperature and $\mathrm{Mg}^{2+}$ concentration. Geochimica Et Cosmochimica Acta 71, 4704-4715.

Kluge, T., Affek, H.P., Dublyansky, Y., Spoetl, C., 2014. Devils Hole paleotemperatures and implications for oxygen isotope equilibrium fractionation. Earth and Planetary Science Letters 400, 251-260.

Kolodny, Y., Stein, M., Machlus, M., 2005. Sea-Rain-Lake relation in the Last Glacial East Mediterranean revealed by a $\delta^{18} \mathrm{O} \delta^{13} \mathrm{C}$ in Lake Lisan aragonites. Geochimica Et Cosmochimica Acta 69, 4045-4060.

Langgut, D., Almogi-Labin, A., Bar-Matthews, M., Weinstein-Evron, M., 2011. Vegetation and climate changes in the South Eastern Mediterranean during the Last Glacial-Interglacial cycle (86 ka): new marine pollen record. Quaternary Science Reviews 30, 3960-3972.

Leng, M.J., 2006. Isotopes in palaeoenvironmental research. Springer, Dordrecht.

Lev, L., Almogi-Labin, A., Mischke, S., Ito, E., Ben-Avraham, Z., Stein, M., 2014. Paleohydrology of Lake Kinneret during the Heinrich event H2. Palaeogeography Palaeoclimatology Palaeoecology 396, 183-193.

Lev, L., Boaretto, E., Heller, J., Marco, S., Stein, M., 2007. The feasibility of using Melanopsis shells as radiocarbon chronometers, Lake Kinneret, Israel. Radiocarbon 49, 1003-1015.

Li, H.C., Ku, T.L., 1997. $\delta^{13} \mathrm{C}-\delta^{18} \mathrm{O}$ covariance as a paleohydrological indicator for closed-basin lakes. Palaeogeography Palaeoclimatology Palaeoecology 133, 69-80. 
665 Martrat, B., Grimalt, J.O., Lopez-Martinez, C., Cacho, I., Sierro, F.J., Flores, J.A., Zahn, R., 666 Canals, M., Curtis, J.H., Hodell, D.A., 2004. Abrupt temperature changes in the Western 667 Mediterranean over the past 250,000 years. Science 306, 1762-1765.

668 McGarry, S., Bar-Matthews, M., Matthews, A., Vaks, A., Schilman, B., Ayalon, A., 2004. 669 Constraints on hydrological and paleotemperature variations in the Eastern Mediterranean region 670 in the last 140 ka given by the delta D values of speleothem fluid inclusions. Quaternary Science 671 Reviews 23, 919-934.

672 Moshkovitz, S., Magaritz, M., 1987. Stratigraphy and isotope records of middle and late 673 Pleistocene mollusks from a continuous corehole in the hula basin, northern Jordan Valley, 674 Israel. Quaternary Research 28, 226-237.

675 Nadel, D., Belitzky, S., Boaretto, E., Carmi, I., Heinemeier, J., Werker, E., Marco, S., 2001. New 676 dates from submerged Late Pleistocene sediments in the Southern Sea of Galilee, Israel. 677 Radiocarbon 43, 1167-1178.

678 Olivier, G., 1801. Voyage dans l'Empire Ottoman, l'Egypte et la Perse, Paris: Agasse.

679 Olivier, G., 1804. Voyage dans l'Empire Ottoman, l'Egypte et la Perse, Paris: Agasse.

680 Peirce, B., 1852. Criterion for the rejection of doubtful observations. Astronomical Journal 45, 681 161-163.

682 Rambeau, C.M.C., 2010. Palaeoenvironmental reconstruction in the Southern Levant: synthesis, 683 challenges, recent developments and perspectives. Philosophical Transactions of the Royal 684 Society a-Mathematical Physical and Engineering Sciences 368, 5225-5248.

685 Rindsberger, M., Magaritz, M., Carmi, I., Gilad, D., 1983. The relation between air-mass 686 trajectories and the water isotope composition of rain in the Mediterranean-Sea area. 687 Geophysical Research Letters 10, 43-46.

688 Roberts, N., Jones, M.D., Benkaddour, A., Eastwood, W.J., Filippi, M.L., Frogley, M.R., Lamb, 689 H.F., Leng, M.J., Reed, J.M., Stein, M., Stevens, L., Valero-Garces, B., Zanchetta, G., 2008. 
690 Stable isotope records of Late Quaternary climate and hydrology from Mediterranean lakes: the 691 ISOMED synthesis. Quaternary Science Reviews 27, 2426-2441.

692 Robinson, S.A., Black, S., Sellwood, B.W., Valdes, P.J., 2006. A review of palaeoclimates and 693 palaeoenvironments in the Levant and Eastern Mediterranean from 25,000 to 5000 years BP: 694 setting the environmental background for the evolution of human civilisation. Quaternary 695 Science Reviews 25, 1517-1541.

696 Ross, S.M., 2003. Peirce's criterion for the elimination of suspect experimental data. Journal of 697 Engineering Technology 20, 38-41.

698 Rossignol-Strick, M., Paterne, M., 1999. A synthetic pollen record of the eastern Mediterranean 699 sapropels of the last $1 \mathrm{Ma}$ implications for the time-scale and formation of sapropels. Marine 700 Geology 153, 221-237.

701 Schneider, R.R., Muller, P.J., Ruhland, G., 1995. Late Quaternary surface circulation in the East 702 Equatorial South-Atlantic - evidence from alkenone sea-surface temperatures. Paleoceanography $70310,197-219$.

704 Serruya, C., 1978. Lake Kinneret. W. Junk, The Hague ; Boston.

705 Stein, M., 2001. The sedimentary and geochemical record of Neogene-Quaternary water bodies 706 in the Dead Sea Basin - inferences for the regional paleoclimatic history. Journal of 707 Paleolimnology 26, 271-282.

708 Stein, M., 2014. Late Quaternary limnological history, in: Zohary, T., Sukenik, A., Berman, T., 709 Nishri, A. (Eds.), Lake Kinneret, ecology and management. Springer.

710 Tang, J., Dietzel, M., Fernandez, A., Tripati, A.K., Rosenheim, B.E., 2014. Evaluation of kinetic 711 effects on clumped isotope fractionation $\left(\Delta_{47}\right)$ during inorganic calcite precipitation. Geochimica 712 Et Cosmochimica Acta 134, 120-136.

713 Tchernov, E., 1975. The molluscs of the Sea of Galilee. Malacologia 15, 147-184. 
714 Tsvieli, Y., Zangvil, A., 2005. Synoptic climatological analysis of 'wet' and 'dry' Red Sea 715 Troughs over Israel. International Journal of Climatology 25, 1997-2015.

716 Wang, Z.G., Schauble, E.A., Eiler, J.M., 2004. Equilibrium thermodynamics of multiply 717 substituted isotopologues of molecular gases. Geochimica Et Cosmochimica Acta 68, 47797184797.

719 Xu, X., Trumbore, S.E., Zheng, S., Southon, J.R., McDuffee, K.E., Luttgen, M., Liu, J.C., 2007.

720 Modifying a sealed tube zinc reduction method for preparation of AMS graphite targets:

721 Reducing background and attaining high precision. Nuclear Instruments \& Methods in Physics

722 Research Section B-Beam Interactions with Materials and Atoms 259, 320-329.

723 Zaarur, S., Affek, H.P., Brandon, M.T., 2013. A revised calibration of the clumped isotope 724 thermometer. Earth and Planetary Science Letters 382, 47-57.

725 Zaarur, S., Olack, G., Affek, H.P., 2011. Paleo-environmental implication of clumped isotopes in 726 land snail shells. Geochimica et Cosmochimica Acta 75, 6859-6869.

727

728 
729 Table 1. Isotopic data of modern Melanopsis shells

730

731 GBY are samples from Gesher Bnot Ya'aqov, GHP is Gesher Hapkak, BIV is a bivalve sample.

$732 *$ Published mean annual value (Serruya, 1978).

733 Ghosh and abs refers to the Ghosh et al. (2006) and absolute reference frame (Dennis et al., 734 2011), respectively.

735 Carbonate and water values are references to the VPDB and VSNOW standards respectively. 
736 Table 2. Isotopic data of fossil Melanopsis samples.

737

738 GBY are samples from Gesher Bnot Ya'aqov, BY and JR samples are from the Sea of Galilee 739 and GSH is the sample from Gesher Sheikh Huseain. BIV are bivalve samples.

740 Ghosh and abs refers to Ghosh et al. (2006) and absolute reference frame (Dennis et al., 2011), 741 respectively.

742 Carbonate and water values are references to the VPDB and VSNOW standards respectively. 


\section{$744 \quad$ Figure captions:}

745 Figure 1. Map of study area and sample collection sites. (1) Mount Hermon; (2) Dan Spring; (3) 746 Gesher Yosef; (4) Hula Basin; (5) Gesher B’not Ya’akov and Gesher Hapkak; (6) Gonen Spring;

747 (7) Geinosar Beach; (8) Beit Yerach; (9) Ma'agan Beach; (10) Soreq cave; (11) Ein Gedi; (12) 748 Ein Tamar.

749

750

Figure 2. High resolution $\delta^{18} \mathrm{O}$ of modern Melanopsis shells from the Sea of Galilee (a), Gesher 751 Bnot Ya'aqov (b) and Dan Spring (c). Black lines are running mean of the data of a 5 points 752 average.

753

754 Figure 3. $\Delta_{47}$ (a) and $\delta^{18} \mathrm{O}$ (b) of Melanopsis shell aragonite compared to the temperature 755 dependence of the carbonate clumped isotope thermometer calibration (Zaarur et al., 2013) and 756 of the oxygen isotope fractionation $\left(1000 \ln ^{18} \alpha\right)$ thermometer calibration (Kim et al., 2007b). 757 Average error bars given are $\pm 2 \sigma$. All $\Delta_{47}$ are given in the absolute reference frame.

Figure 4. A comparison of (a) temperature records from Melanopsis (Mel.) and from the Hula 760 Valley and sea of Galilee to temperature records from the Mediterranean Sea (Almogi-Labin et 761 al., 2009) and Soreq Cave (Affek et al., 2014); (b) $\delta^{18} \mathrm{O}_{\text {carbonate }}$ of Melanopsis (Mel.) shells and 762 speleothem from Soreq Cave (Bar-Matthews et al., 2003); (c) $\delta^{18} \mathrm{O}_{\text {water }}$ of calculated paleo-waters 763 of the Hula and Sea of Galilee. Red diamonds and blue circles represent Melanopsis samples 764 from the Sea of Galilee and the Jordan River respectively. Small green circles in (a) and black 765 line in (b) and (c) represent Soreq cave data. 


\begin{tabular}{|c|c|c|c|c|c|c|c|c|c|c|}
\hline Sample & Species & $\mathbf{a}$ & $\begin{array}{c}\hat{\sigma}^{-13} \mathrm{O}_{c} \\
{[\mathrm{~S}}\end{array}$ & $\begin{array}{c}\delta^{13} C_{e} \\
{\left[N_{0}\right]}\end{array}$ & 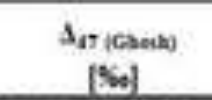 & $\begin{array}{c}\Delta_{a 7, a b} \\
{[\mathrm{Ban}]}\end{array}$ & $\begin{array}{c}\text { Temp. }\left(\Delta_{47}\right) \\
{ }^{\circ C}\end{array}$ & $\begin{array}{c}\text { Teup. } \\
\text { Measured }{ }^{\circ} \mathrm{C}\end{array}$ & $\begin{array}{c}\dot{o}^{18} \mathrm{O}_{\text {mate }} \\
\text { Calculated }[\% \omega]\end{array}$ & $\begin{array}{c}6^{18} \mathrm{O}_{\text {mater }} \\
\text { Measured }[\% \text { o] }\end{array}$ \\
\hline Ein Gedi & Melanopsis buccinaidea & 5 & $-6,05 \pm 0.02$ & $-9.23=0.05$ & $0.647 \pm 0.006$ & 0.707 & $24.3 \pm 1.5$ & 23 & $-4.59=0.3$ & -2.99 \\
\hline Ein Tama & Melanopsis buccinoidea & 3 & $-6.94=0.05$ & $-5.32=0.01$ & $0.655=0.003$ & 0.716 & $22.2=0.8$ & 25 & $-5.91=0.2$ & -3.50 \\
\hline Ma'azan Beach" & toindentified & 5 & $-1.31=0.04$ & $-3.85=0.02$ & $0.651=0.015$ & 0.711 & $23.6=3.6$ & 24 & $0.01=0.7$ & aso \\
\hline Gooen Spring & Melanopsis buccinoidea. & 5 & $-6.20 \pm 0.02$ & $-14.17=0.06$ & $0.653=0.013$ & 0.713 & $23.0 \pm 3.2$ & 22 & $-5.02=0.6$ & -4.19 \\
\hline Dan Spring & Melanopsis buccinosidea & 5 & $-6.02 \pm 0.03$ & $-8.87=0.05$ & $0.695=0.012$ & 0.758 & $13.1=2.6$ & 16 & $-6.91=0.6$ & -4.97 \\
\hline Gesher Yosef & Melconopsis buceinoidea $x$ costata & 7 & $-6.41=0.04$ & $-8.80=0.06$ & $0.654=0.004$ & 0.714 & $22.6=1.0$ & 21 & $-530=02$ & $-3,50$ \\
\hline GHP & Melanopsis casfata & 3 & $-6.33 \pm 0.06$ & $-8.78=0.03$ & $0.645=0.008$ & 0.705 & $24.7=2.0$ & 22 & $-4.79=0.4$ & -4.58 \\
\hline GBY 2003 & Aclanopsis buccinoidea & 3 & $-6,48 \pm 0,03$ & $-12.58=0.02$ & $0.642=0.011$ & 0.702 & $25.6 \pm 28$ & & $-4.77=0.6$ & \\
\hline GBY IC & Melanopsis costata & 6 & $-6.33=0.04$ & $-9.08=0.06$ & $0.649=0.015$ & 0,709 & $24.1=3.6$ & 21 & $-4.91=0.7$ & $-4,42$ \\
\hline GBY $1 \mathrm{~b}$ & Melariopsis costata & 4 & $-6.86=0.03$ & $-8.73=0.04$ & $0.645=0.007$ & 0,703 & $24.7=1.7$ & 21 & $-3.32=0.3$ & $-4,42$ \\
\hline GBY $1 \mathrm{a}$ & Melanopsis castata & 5 & $-6.40 \pm 0.02$ & $9.32=0.03$ & $0.636 \pm 0.011$ & 0.695 & $27.2 \pm 2.7$ & 21 & $-4.37=0.5$ & .4 .42 \\
\hline GHP BIV & unindentified & 3 & $-6.66 \pm 0.01$ & $-14.42=0.09$ & $0.624 \pm 0.005$ & 0.683 & $30.2 \pm 1.4$ & 22 & $-4.04=0.3$ & $-4,58$ \\
\hline
\end{tabular}




\begin{tabular}{|c|c|c|c|c|c|c|c|c|c|c|}
\hline Sample & Species & $\begin{array}{l}{ }^{14} \mathrm{C} \\
\text { yr BP } \\
\end{array}$ & $\begin{array}{c}\text { Calibrated Age } \\
\mathrm{Ka} \\
\end{array}$ & n & $\begin{array}{c}\delta^{18} \mathrm{O}_{e} \\
{[\% 6]}\end{array}$ & $\begin{array}{c}{ }^{13} \mathrm{C}_{e} \\
{[\% 6]}\end{array}$ & $\begin{array}{c}\Delta_{47 \text { (Gbast) }} \\
{[\% 06]}\end{array}$ & $\begin{array}{l}\Delta_{4}, a b s \\
{[\% o]}\end{array}$ & $\begin{array}{c}\text { Temp } \\
{\left[{ }^{\circ} \mathrm{C}\right]}\end{array}$ & $\begin{array}{c}\delta^{18} \mathrm{O} \text { (water) } \\
{[\% \circ]}\end{array}$ \\
\hline GBY 8 & Melanopsis costata & $2740=15$ & $0.7 \pm 0.01$ & 4 & $-4.48=0.03$ & $-1.27=0.04$ & $0.657=0.010$ & 0.717 & $22.0=2.4$ & $-3.5=0.5$ \\
\hline GBY 7 & Melanopsis costata & $7180=15$ & $5.9 \pm 0.01$ & 4 & $-5.40=0.03$ & $-4.13=0.03$ & $0.634=0.009$ & 0.693 & $27.7 \pm 2.2$ & $-3.3=0.4$ \\
\hline GBY $5 b$ & Melanopsis costata & $7315=20$ & $6.1=0.07$ & 5 & $-4.10=0.04$ & $-3.24=0.06$ & $0.625=0.008$ & 0.684 & $29.9=2.1$ & $-1.5=0.4$ \\
\hline GBY $9 b$ & Melanopsis costata & $8610=25$ & $7.5=0.02$ & 5 & $-5.62=0.03$ & $-1.79=0.05$ & $0.636=0.011$ & 0.696 & $27.1=2.8$ & $-3.6=0.5$ \\
\hline GBY 5a & Melanopsis costata & $10375=20$ & $9.4=0.05$ & 4 & $-5.67 \pm 0.04$ & $-2.50=0.12$ & $0.635=0.009$ & 0.694 & $27.5 \pm 2.3$ & $-3.6=0.4$ \\
\hline GBY $4 \mathrm{~b}$ & Melanopsis costata & $10940=25$ & $10,1=0.09$ & 6 & $-5.41 \pm 0.05$ & $-3.72=0.06$ & $0.644=0.009$ & 0.704 & $25.1=2.3$ & $-3.8=0.5$ \\
\hline GBY $4 a$ & Melanopsis costata & $10985=25$ & $10.1 \pm 0.09$ & 5 & $-4.67 \pm 0.08$ & $-2.55=0.03$ & $0.632=0.012$ & 0.691 & $28.3 \pm 3.2$ & $-2.4=0.6$ \\
\hline GBY 9a & Melanopsis costata & $11050=25$ & $10.2 \pm 0.01$ & 4 & $-4.64 \pm 0.05$ & $-1.07=0.08$ & $0.632=0.007$ & 0.691 & $28.1=1.9$ & $-2.4 \pm 0.4$ \\
\hline GBY 6 & Melanopsis costata & $16485=40$ & $17.6 \pm 0.24$ & 4 & $-6.41=0.02$ & $-6.71=0.02$ & $0.656=0.012$ & 0.716 & $22.2 \pm 2.8$ & $-5.4=0.6$ \\
\hline GBY $3 b$ & Melasopsis costata & $19270 \pm 60$ & $20.7 \pm 0.28$ & 6 & $-6.17 \pm 0.05$ & $-7.34 \pm 0.06$ & $0.647 \pm 0.009$ & 0.707 & $24.6 \pm 3.5$ & $-4.7 \pm 0.7$ \\
\hline GBY $3 \mathrm{a}$ & Melanopsis costata & $20030=70$ & $21.7 \pm 0.36$ & 5 & $-5.89 \pm 0,03$ & $-7.49=0.03$ & $0.660=0.009$ & 0.721 & $21.1 \pm 2.2$ & $-5.1=0.5$ \\
\hline GBY MT & Melanopsis comugata & $>48500=0$ & $50.0=0.00$ & 4 & $-7.22 \pm 0.02$ & $-6.47 \pm 0.03$ & $0,640=0,008$ & 0.700 & $26.1 \pm 2.0$ & $-5.4=0.4$ \\
\hline BY 1-5b & Melanopsis castata & $5700=20$ & $5.6 \pm 0.02$ & 5 & $-0.64 \pm 0.03$ & $-1.64=0.04$ & $0.634=0.010$ & 0.693 & $27.7 \pm 2.5$ & $1.5=0.5$ \\
\hline JR 8.1 & Melanopsis costata & $7540=20$ & $7.6 \pm 0.02$ & 5 & $-0.51 \pm 0.03$ & $-0.98=0.04$ & $0.665=0.009$ & 0.726 & $20.1=2.3$ & $0.1=0.5$ \\
\hline R \&-1 b & Melanopsis costata & $7540 \pm 20$ & $7.6 \pm 0.00$ & 3 & $-1.70 \pm 0.07$ & $-2.42=0.09$ & $0.646=0.002$ & 0.706 & $24.6 \pm 0.6$ & $-0.2 \pm 0.1$ \\
\hline BY 1.4 & Melanopsis buecinoidea & $19020=60$ & $22.0=0.32$ & 5 & $-4.79 \pm 0.04$ & $-7.28=0.02$ & $0.671=0.008$ & 0.732 & $18.6 \pm 1.9$ & $-3.3=0.8$ \\
\hline BY 1-1 & Melanopsis buccinoidea & $19510=60$ & $22.5=0.29$ & 5 & $-4.11 \pm 0.05$ & $-7.34=0.06$ & $0.656=0.02$ & 0.716 & $22.5 \pm 4.4$ & $-1.8=0.3$ \\
\hline GSH & Melanopsis buccinoidea & $36390=400$ & $40.5 \pm 0.89$ & 5 & $-2.80=0.14$ & $-4.80=0.07$ & $0.661=0.010$ & 0.721 & $21.1=2.5$ & $-0.8=-0.7$ \\
\hline \multirow{2}{*}{\multicolumn{2}{|c|}{$\begin{array}{l}\text { GBY } 4 \text { BIV unidentified } \\
\text { GBY } 5 \text { BIV Corbicula spec. }\end{array}$}} & $11195=25$ & $10.0 \pm 0.09$ & 3 & $-6.67 \pm 0.03$ & $-7.39=0.09$ & $0.646 \pm 0.018$ & 0.705 & $24.9 \pm 4.4$ & $-5.1 \pm 0.9$ \\
\hline & & $12605 \pm 30$ & $12.1 \pm 0.17$ & 3 & $-6.72 \pm 0.04$ & $-7.49 \pm 0.07$ & $0.627 \pm 0.012$ & 0.686 & $29.6 \pm 3.2$ & $-4.2 \pm 0.6$ \\
\hline
\end{tabular}




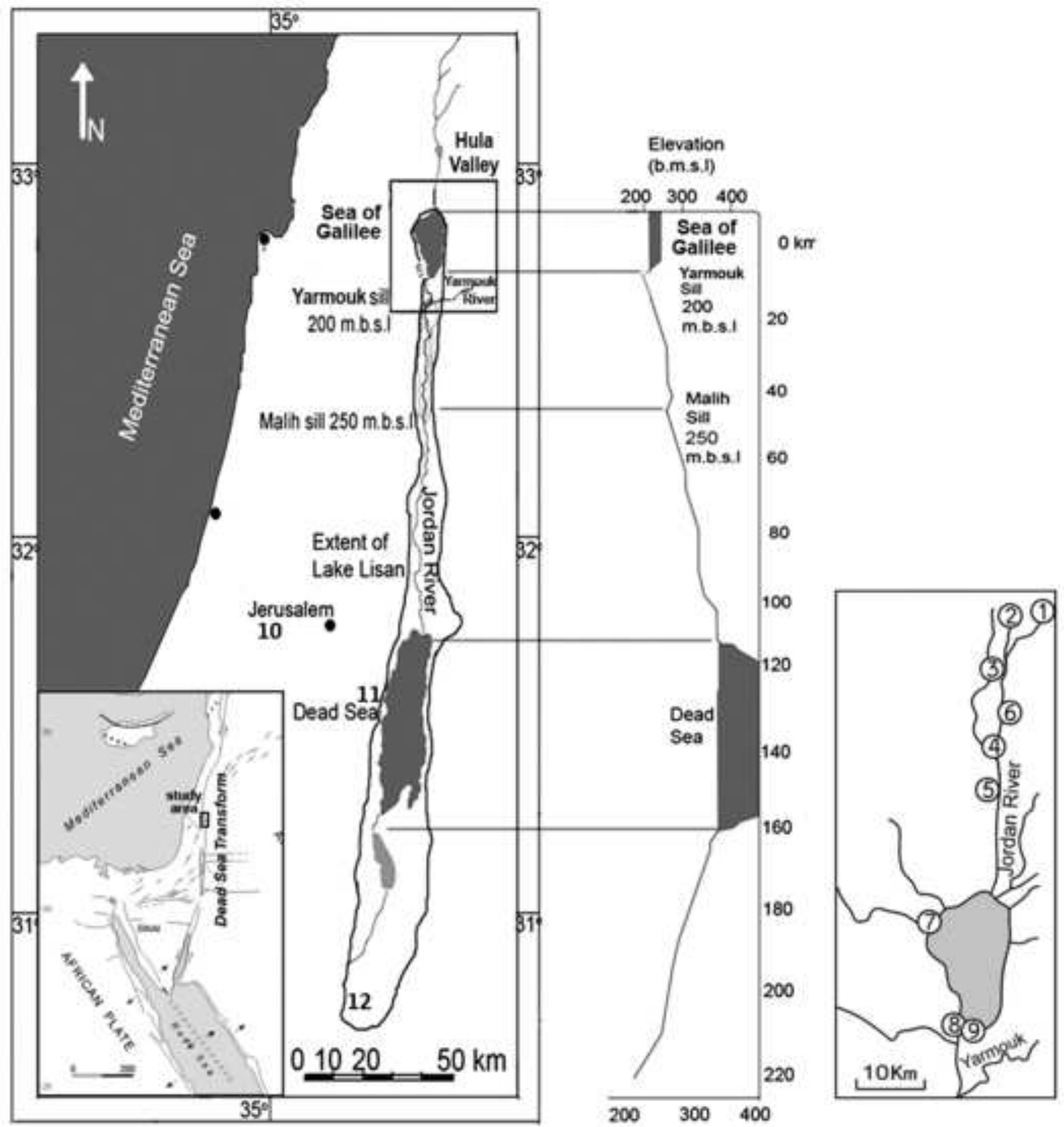



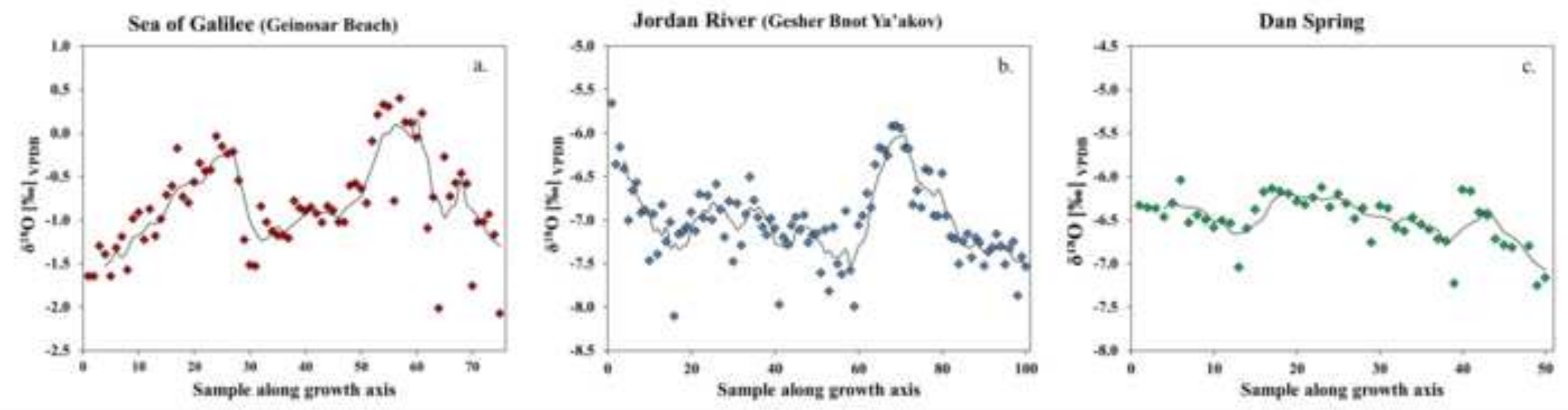


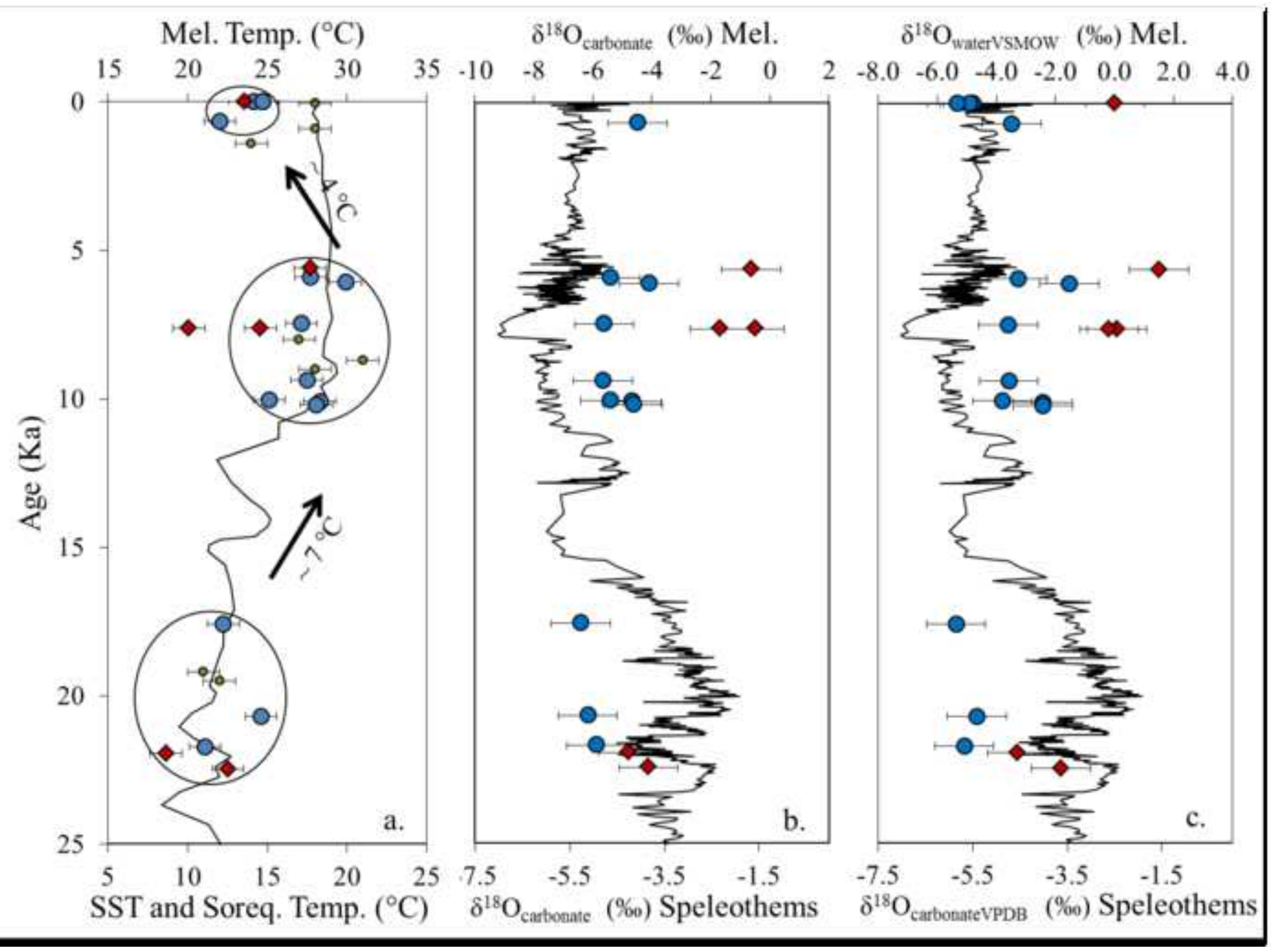

